\title{
Translating technological innovation into efficiency: the case of US public $P \& C$ insurance companies
}

\author{
Davide Lanfranchi ${ }^{1}$ D $\cdot$ Laura Grassi $^{1}$ D
}

Received: 7 October 2020 / Revised: 2 July 2021 / Accepted: 14 August 2021 /

Published online: 13 September 2021

(c) The Author(s) 2021

\begin{abstract}
In recent years, Insurtech innovations, driven by technologies such as artificial intelligence and blockchain, emerged in the insurance industry, with the promise of improving efficiency. However, while the positive impact of technology on insurance companies' efficiency is expected, literature assessing it empirically is scarce, when it comes to recent technological change. Focusing on the US public P\&C insurance sector in the period 2012-2018 and relying on both nonparametric (two stage DEA) and parametric (SFA) approaches, it emerges that on average insurance companies were not able to leverage on technological innovations to improve their efficiency. On average a relative level of efficiency among companies, according to a two stage DEA model, was quite stable in time, while the SFA approach shows that the distance between efficient and less efficient firms slightly increased. Moreover, we found one very efficient firm, almost a leader of the market in terms of efficiency, and a homogeneous group of followers, indicating that there is vast scope for improvement for less efficient companies. Nevertheless, even the most efficient company impaired its efficiency over time, suggesting that neither the leader nor on average the followers properly leveraged technology to improve their efficiency. In a competitive scenario, with new players' entrance and fierce competition, inertia may seriously affect their positioning. Academicians, managers and policymakers should carefully consider the effects that a non-improvement of efficiency following technological change may have on market structure, competition and regulations, potentially opening to further discussion on how technological innovations adoption should be facilitated.
\end{abstract}

Keywords Efficiency · Insurance · Technology · Insurtech · Competition · Innovation

Davide Lanfranchi

davide.lanfranchi@polimi.it

1 School of Management, Politecnico di Milano, Milan, Italy 


\section{Introduction}

"In a world of increasing uncertainty and dynamics, the economic and social importance of being insured seems undisputed" (Stoeckli et al., 2018, p. 287). The recent pandemic related to COVID-19 revealed to the public the relevance of the insurance industry for its impact on daily life. From an economic point of view, insurance is fundamental by dealing with the negative consequences of economic activities that would occur in its absence (Zweifel \& Eisen, 2012), while from a social point of view, insurance is crucial by providing social protection mechanisms (The Geneva Association, 2012), in turn positively affecting country's economy (Grmanová \& Strunz, 2017). Due to their conservative attributes, insurance companies traditionally struggled with innovation (Nam, 2018). However, new developments and changes in society and in economy affect the demand for insurance (Bohnert et al., 2019), and considering socio-economic changes to which it is connected in several ways (Bohnert et al., 2019), the insurance industry needs to innovate. In recent years, we are observing the increasing relevance and disruptive nature of digitalization (Fitzgerald et al., 2014) and the emergence of Insurtech, "a phenomenon comprising innovations of one or more traditional or non-traditional market players exploiting information technology to deliver solutions specific to the insurance industry" (Stoeckli et al., 2018, p. 289). Interest in the possibilities arising from digital innovation (Deloitte, 2018), focusing in particular on the impact that new technologies such as artificial intelligence (McKinsey, 2018a), blockchain (BCG, 2018) and big data (Corlosquet-Habart \& Janssen, 2018) may have on the increase of efficiency (McKinsey, 2018b) is noticeable for traditional insurance companies, practitioners and academicians.

Academic literature highlights how recent technological innovation in the insurance sector brings with it the promise of increasing efficiency (Lin \& Chen, 2020): for instance, artificial intelligence can bring efficiency in the personalization of insurance policies (Al-witwit \& Ibrahim, 2020); blockchain, by disintermediating, could bring in a more efficient approach by increasing speed and reducing costs (Grima et al., 2020); online interfaces and virtual claims adjusters could make the settling and payment of claims following an accident more efficient, concurrently decreasing the likelihood of frauds (Clemente \& Marano, 2020). However, despite the contributions suggesting that a positive effect of new technologies emerged in the last decade on insurance companies' efficiency, literature trying to further investigate this relation is scarce. Not just academicians, but also managers and policymakers should carefully consider the effects that a (non)improvement in efficiency following technological change may have on the market structure, competition and regulations, potentially opening to further discussion on how technological innovations should be grounded and effectively adopted or facilitated.

For this reason, this paper examines with an empirical approach whether insurance companies improved their efficiency, by relying on new technologies.

To do so, the scope of this work is the public property and casualty (P\&C) insurance sector in the United States (US). The US insurance market is the largest 
in the world in terms of total direct premium volume, with a global market share of 39\% in 2019 (Swiss Re Institute, 2020). Furthermore, the United States is the most advanced country in terms of technological innovation in the insurance sector, as suggested for instance by the relevance of the Insurtech startups ecosystem in this country; in terms of investments in Insurtech startups, the US leads the ranking, with nearly $45 \%$ of world Insurtech startups able to attract nearly $50 \%$ of total investments (NTT Data, 2020). Of the two main kinds of insurance, Life insurance, where the insurer invests the insured's savings undertaking to pay a capital or an income in case of a life event, such as death; and P\&C-Property and Casualty insurance, that protects the insured against possible losses deriving from damages to persons or objects (Marchionni, 2006), we concentrate on insurance companies solely in the P\&C insurance business. The P\&C segment is particularly detrimental for the market as it deals with almost any kind of risk (Ilyas \& Rajasekaran, 2019) affecting daily and business continuity. Indeed, process digitalization (such as for sales and distribution) and achievement of higher efficiency are among the top trends in the $\mathrm{P} \& \mathrm{C}$ market according to practitioners (EY, 2019), with the promise of promoting efficiency in processes that are particularly relevant for this kind of insurance (e.g. claim settlements, Clemente \& Marano, 2020). In this context, the US P\&C insurance sector in particular had a relevant growth over the past years: in 2018, this sector has seen a net income increase of $66 \%$ to US $\$ 60$ billion, thanks to a $10.8 \%$ boost in net premiums (Deloitte, 2019).

Therefore, focusing on the US P\&C public insurance sector, the rest of the paper reviews extant literature presenting theoretical and empirical findings on the effect of technological improvement on efficiency. Attention to methodological issues and description of the sample anticipate the discussion of results and conclusions.

\section{Literature review}

Examining the relation between technological change and efficiency requires some elements of theory, hereby presented to introduce empirical evidence and approaches to estimate the relation.

\subsection{Efficiency and technological change: theoretical background}

Efficiency is a condition for survival in a competitive scenario (Fried et al., 1993; Mogos et al., 2021), opening the way for a firm's outperformance in the market (Schaeck \& Cihák, 2014), feeding its stability (Schaeck \& Cihák, 2014). Technology contributes to productivity (Bartelsman et al., 2019), efficiency (Voghouei \& Jamali, 2018) and thus to the ability of the companies to compete (Battese \& Rao, 2002; Sonenshine, 2020).

However, even well managed companies may lose their dominance in the market, failing when disruptive changes in technology emerge (Christensen, 2013). Such a failure can be related to the companies' inability to consider new disruptive 
technologies in a timely manner, but also to their inability to commercialize them successfully (Vecchiato, 2017). When it comes to insurance companies, the industry is experiencing a clear change (McKinsey, 2018b) for the increasing relevance of digitalization (Fitzgerald et al., 2014) and the emergence of Insurtech. Recent technological progress deals not only with the technology itself, but also with the availability of information, affecting the playing field in informationally sensitive markets (Hauswald \& Marquez, 2003). Technological innovation in the insurance sector brings several benefits such as better understanding of underlying insurance risks and increasing efficiency and lowering costs for insurers, intermediaries, and customers (Lin \& Chen, 2020), contributing, as innovation in general, to economic growth (Pellegrino \& Piva, 2020).

\subsection{Efficiency and technological change: empirical evidence}

Efficiency measurement is a fast-growing area in business and economics literature (Biener et al., 2016) and different recent contributions analyzed efficiency of $\mathrm{P} \& \mathrm{C}$ insurance industry, adopting from time to time different geographical perspectives, from national (e.g. South Africa, Alhassan \& Biekpe, 2016) or India (Ilyas \& Rajasekaran, 2019)) to multi-country (e.g. Europe, as in Jarraya and Bouri, 2015). Some studies analyzed the efficiency of the US insurance industry (e.g. Copeland and Cabanda, 2018), focusing on 2011-2013, and Cummins and Xie, 2016, focusing on 1993-2011). Eling and Luhnen (2010) and Ferro and Leòn (2018) provided a review on studies analyzing efficiency in the insurance sector. In several cases, results show that there is significant room for improvement in terms of efficiency of insurance companies, as their actual level is moderate to low (Cummins \& Xie, 2016; Ilyas \& Rajasekaran, 2019; Worthington \& Hurley, 2002), even compared to other financial segments (Cummins, 1999). Said otherwise, there is substantial room for improvement in efficiency. A further stimulus for increasing efficiency came from relevant technological innovations emerging in the insurance panorama (Lin \& Chen, 2020), in particular starting from 2012 (Willis Tower Watson, 2018), that were capable of making relevant insurance processes more efficient (Clemente \& Marano, 2020). Some contributions had the purpose of studying the evolution of efficiency during time due to technological change. Ferro and León's (2018) results show that the productivity of the industry was not improving over the years, and one of the causes was the non-technological improvement. Companies were not investing in technology or the investments turned in no positive effect on productivity (premiums) (Ferro \& León, 2018).

Despite the presence of works studying efficiency levels in the insurance industry in recent years (Camino-Mogro \& Bermúdez-Barrezueta, 2019; Nguyen \& Worthington, 2020), they do not further investigate the effect of technological change. In the light of previous results, showing a moderate efficiency in the industry and of recent technological innovations with the potential to change the industry (Eling \& Lehmann, 2018), in particular in the country mostly affected by innovative technological applications in insurance [i.e. the US (NTT Data, 2020)], we deem very relevant to contribute to the understanding of the effect that recent technological 
innovations have, potentially challenging the validity of former results and affecting the dynamics of market players' competition. To the best of our knowledge, there are no timely contributions on insurance companies' efficiency and on the effect of technological change focused on the US in recent years (post-2012).

\subsection{Efficiency and technological change: measures, methods and approaches}

Measurements support us in quantifying such theoretical underpinnings (Fried et al., 1993). To estimate efficiency, the emergence of frontier methodologies has been a relevant development in modern economics, encompassing the limitations of financial ratios (Huang \& Eling, 2013). The basic idea is to identify efficient ${ }^{1}$ companies, namely companies that maximize their output considering the inputs at their disposal, with respect to non-efficient ones. The group of efficient companies forms the efficient frontier. Hence, for all companies, efficiency is measured with reference to a frontier consisting of the dominant companies in the industry. Frontier efficiency measures summarize a company's efficiency in a single measure (values from 0 , non-efficient company, to 1 , fully efficient company) that checks for differences among companies according to a sophisticated multidimensional framework that has its roots in economic theory (Cummins \& Weiss, 2013) and implies some reasoning on the production function. However, new or innovative technological processes appear over time, these imply different ways of combining inputs, or different ways of combining processes (technology set). Any enlargement of the corresponding technology set is, by definition, a technological change (Gomulka, 2006). The addition of an efficient technology moves the production frontier further outwards, and thus any such movement indicates the presence of technological progress within the company (Gomulka, 2006).

The existing different approaches focus on the estimation of the production function, following either a parametric or non-parametric approach. Danquah et al. (2018) and Delhausse et al. (1995) applied parametric techniques, stochastic frontier analysis (SFA) in particular, which provide techniques for modeling the frontier within a regression framework in order to estimate efficiency. Other authors applied non-parametric techniques, which utilize linear programing techniques to estimate the frontier and provide relative assessment (Tuzcu \& Ertugay, 2020) such as Data Envelopment Analysis (DEA) (Barros et al., 2005; Cummins \& Turchetti, 1996; Hesarzadeh, 2020; Nguyen \& Worthington, 2020; Nourani et al., 2020; Shieh et al., 2020), and two-stage DEA ( $\mathrm{Li}$ et al., 2018). The choice of the methodology for estimating efficient frontiers has generated debates in the literature, with some scholars supporting the parametric approach (Berger, 1993; Greene, 2008) and others the nonparametric one (Cooper et al., 2011), with no clear conclusion. The main advantage traditionally offered by the parametric approaches (hence SFA) in comparison with the nonparametric ones (such as DEA) is that SFA allows to distinguish randomness from efficiency (Ferro and Leòn, 2018). On the other hand, the primary

\footnotetext{
${ }^{1}$ Even though in literature this is defined as "technical efficiency" (Cummins and Weiss, 2013), for the sake of simplicity we will refer to it as "efficiency" in this paper.
} 
advantage traditionally given by nonparametric approaches as DEA is to avoid misspecification of the functional form or the probability distributions assumed for error terms, which could confound the efficiency estimates with specification errors. Some authors are then opting for using both techniques (e.g. Ur-Rehman et al., 2020), to leverage on advantages of both approaches.

\section{Methodology}

This work studies efficiency in the US P\&C public insurance sector by estimating the production function, which connects the level of output, given the inputs, focusing on technical efficient companies, namely the ones capable of producing the highest level of output conditional on input use levels, consistently with previous literature (Ferro and Leòn, 2018). Therefore, observed output $\left(y_{i}\right)$ is connected to the production function $f\left(\boldsymbol{x}_{i} ; \beta\right)$ and to input $\left(\boldsymbol{x}_{i}\right)$ as:

$$
y_{i}=a_{i} f\left(x_{i} ; \beta\right), \quad 0<a_{i} \leq 1
$$

In literature, different approaches for identifying outputs and inputs co-exist.

\subsection{Output measure}

As reported by Cummins and Weiss (2013), there are three main approaches to measure outputs in financial services-the asset intermediation approach, the user-cost approach, and the value-added approach. The intermediation approach considers financial companies as pure financial intermediaries and consider assets as outputs. This approach is inappropriate for $\mathrm{P} \& \mathrm{C}$ insurers as they provide further services in addition to financial intermediation. The user-cost method determines whether a financial product is an input or output depending on its net contribution to the revenues. This approach is problematic for the insurance industry owing to policies comprising many services, which are priced implicitly. Under the third approach - the value-added approach - categories having significant value-added are employed as important outputs: this approach is widely adopted in literature (Delhausse et al., 1995; Fecher et al., 1993; Fuentes et al., 2005; Rai, 1996), and current research relies on this approach as well, with premiums as output.

\subsection{Input measure}

Concerning input variables, consistently with Rai (1996), variables adopted in this work are claims, labor, and capital. The evaluation of the premiums that will be collected from insured entities (customers) $\left(\mathrm{y}_{\mathrm{i}}\right)$ starts from estimating the so-called fair premium, hence the amount needed to cover the expected losses that the customer may suffer during the protection period and that the insurance company will have to repay (hence, the claims) (Zweifel \& Eisen, 2012). Claims are hence considered as inputs, being a determinant of the amount of premiums that an insurance company will collect at the beginning of the protection period. Along with the claim's current 
value, we considered the reserves, which refer to the estimated subsequent compensations costs, the related direct and settlement costs, the provision for late reporting and, more in general, the charges deriving from the part of the risk not yet concretized. On top of it, premiums loadings are charged to count for other expenses, such as operating and administrative expenses, which we will consider under the labor input. As insurance companies sell their policies through agents relying on their own staff for back-office work (Ferro and Léon, 2018), labor is composed mainly by brokers' labor (accounting for the larger part of commissions) and home office labor (hence wages). Finally, to perform insurance activities, regulators require a minimum of equity capital from insurance companies (Zweifel \& Eisen, 2012), to insure solvency also in case of unexpected losses. Capital, the third input considered, has its roots in Adam Smith's Wealth of Nations as "In order to give this security, however, it is necessary that the insurers should have a very large capital" (Smith, 2007, p. 586).

\subsection{Production function estimation}

To estimate the production function and to cross-check our results, we adopted both a nonparametric (two stage-DEA) and a parametric approach (SFA), in the light of the above-mentioned benefits and drawbacks of each technique.

\subsubsection{Two stage-DEA}

DEA is a method that allows measuring efficiency of companies relying on linear programing techniques, to envelop observed input-output vectors as tightly as possible to build the efficiency frontier (Boussofiane et al., 1991). By adding weight constraints, DEA models can be subdivided in terms of returns to scale. Charnes et al. (1978) originally proposed the efficiency measurement of companies for constant returns to scale (CRS) assuming all companies were operating at their optimal scale. Banker et al. (1984) introduced the variable returns to scale (VRS) efficiency measurement model, allowing hence the breakdown of efficiency in DEA into technical and scale efficiencies. The concept of frontier is important for the analysis of efficiency, as we measure efficiency as the relative distance from the frontier. DEA models can be divided into input-oriented models, which minimize inputs while respecting the given output levels, and output-oriented models, which maximize outputs without requiring higher input quantities. In both cases, efficiency is measured in terms of a proportional change in inputs or outputs.

Companies that are technically not efficient operate at points in the interior of the frontier and will have a DEA score lower than 1 . In the input-oriented model, the score indicates the percentage of input that the company should use to become efficient, given a certain output level. In the output-oriented model, the score is the output produced by the non-efficient company in percentage of the output produced by an efficient one. A company is called "radial" or "weak" efficient when the DEA score is equal to 1. If, along with this, all slacks [a slack issue arises as the frontier runs parallel to the input or output axes resulting in input/output excesses (Lee \& Ji, 2009)] are zero, the company 
is called efficient in terms of "Pareto-Koopmans" or "strong" efficiency. When the slack issue is neglected and calculated residually, the DEA model becomes the singlestage DEA model; to the contrary, two-stage DEA directly faces slacks issues.

To evaluate technological change under the DEA nonparametric approach, it is useful to rely on Malmquist Productivity Index (MPI) that measures the productivity changes in time and can be decomposed to isolate the technology-driven change (Lee et al., 2011). In particular, a technological change factor higher than 1 means that the company was able to improve its technology to gain efficiency, while a factor lower than 1 means that the technological set deteriorated in terms of effects on efficiency.

\subsubsection{SFA}

The basic empirical framework for SFA is a regression specification involving a logarithmic transformation of the production function that adds a random error term $\left(\mathrm{v}_{\mathrm{i}}\right)$, where output is bounded from above by the stochastic frontier $f\left(\boldsymbol{x}_{i} ; \beta\right) e^{v_{i}}$, and $u_{i}=-\ln \left(a_{i}\right) \geq 0$ represents unit specific technical inefficiency. Hence, technical efficiency is recovered as $e^{u_{i}}$

$$
\ln y_{i}=\operatorname{lnf}\left(\boldsymbol{x}_{i} ; \beta\right)+v_{i}-u_{i} .
$$

The application of a SFA technique requires the discussion and choice of a functional form of production function, $f\left(\boldsymbol{x}_{i} ; \beta\right)$, and of a model for unit specific inefficiency, $u_{i}$.

For the functional form of production function, this work will test two well-known forms in literature, the Cobb-Douglas function in the logarithmic form, because of its simplicity and its easy interpretation (Ferro and Leòn, 2018), and the trans-logarithmic function, a more flexible functional form than Cobb-Douglas (Cummins \& Weiss, 2013).

As mentioned, an efficient technology moves the production frontier further outwards (Gomulka, 2006): this change is captured by a linear indication of time in the Cobb-Douglas function and by a quadratic polynomial of time in the trans-logarithmic function. The rate of technological change is given by $\mathrm{T}^{*}=\delta \mathrm{y} / \delta \mathrm{t}$, considering time affecting efficiency due to technological change. If $\mathrm{T}^{*}>0$, technological change is positive, indicating a growth in efficiency, and vice versa.

For unit specific inefficiency functional forms, we will test a version of stochastic frontiers with time-invariant inefficiency and one with time-varying inefficiency. Regarding time-invariant inefficiency, Battese and Coelli (1988) (BC88) proposed a maximum likelihood (ML) estimation of the following Normal-Truncated Normal model:

$$
\begin{gathered}
y_{i t}=\alpha+x_{i t}^{\prime} \beta+\varepsilon_{i t}, \quad i=1, \ldots, N, \quad t=2, \ldots, T_{i} \\
\varepsilon_{i t}=v_{i t}-u_{i} \\
v_{i t} \sim N\left(0, \sigma_{v}^{2}\right)
\end{gathered}
$$




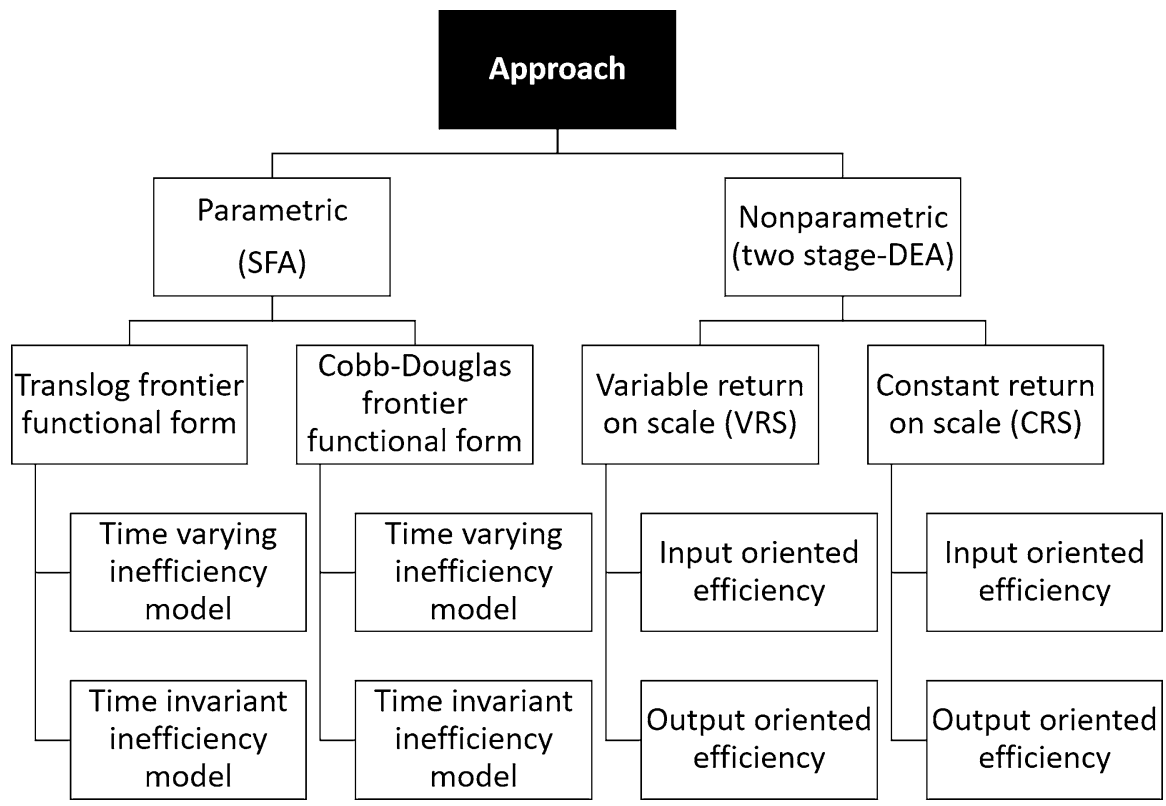

Fig. 1 Summary of adopted approaches and models

$$
u_{i} \sim N^{t r}\left(0, \sigma_{u}^{2}\right)
$$

Regarding time-varying inefficiency, Battese and Coelli (1992) (BC92) proposed a "time decay" ML estimated model for the unit specific inefficiencies:

$$
u_{i t}=g(t) u_{i}, \quad g(t)=e^{\left[-\eta\left(t-T_{i}\right)\right]}
$$

where $T_{i}$ is the last period in the panel for the unit $I$ and the $u_{i}$ are assumed to be independent and identically distributed Truncated Normal. For $\eta$ going to zero, this model converges to BC88. A negative $\eta$ suggests that the relative levels of efficiency among companies is decreasing, hence the gap with the most efficient one is widening.

To give strength to the results with respect to the specific choice of models, this work will hence rely on two different approaches, a parametric (SFA) and a nonparametric approach (two-stage DEA). As a result, for two-stage DEA four models will be involved (input and output oriented, both assuming CRS and VRS), while for SFA, four models will be tested (two functional forms for each production function combined with two models for unit specific inefficiencies, to address the mentioned criticality of parametric approaches of choosing functional forms for frontier and error distribution), as summarized in Fig. 1. 
Table 1 Summary of input and output variables

\begin{tabular}{lll}
\hline Variable & Type & Proxy (FactSet items) \\
\hline Claims & Input & Losses, claims and reserves \\
Labour & Input & Selling, general and admin. \\
& & Expenses and other \\
Capital & Input & Shareholders' equity \\
Premiums & Output & Sales \\
\hline
\end{tabular}

Table 2 Descriptive statistics of input and output variables

\begin{tabular}{lllll}
\hline & Premiums (M\$) & Claims (M\$) & Labor (M\$) & Capital (M\$) \\
\hline Mean & 4602 & 2848 & 1323 & 3728 \\
Standard deviation & 8181 & 5186 & 2274 & 6418 \\
Max & 39,124 & 25,466 & 11,196 & 25,405 \\
Min & 7 & 0 & 4 & 21 \\
Observations & 243 & 236 & 241 & 242 \\
\hline
\end{tabular}

\section{Data collection and analysis}

The measurement of input and output variables (see Table 1) reflects the structure of the sector and the way it is organized. Claim input includes both claims that are already paid as well as new reserves. Labor input includes both selling and general and administrative expenses, reflecting how insurance companies sell policies through agents, earning commissions, and relying on their own staff for back-office work (Ferro and Leòn, 2018). Finally, capital consists in total shareholders' equity. Concerning premiums as a measure of output, we considered sales as a proxy. Data have been obtained from the FactSet Fundamentals database ${ }^{2}$ over the period 2012-2018. Indeed, starting from 2012, technological innovations emerging in the insurance panorama, such as blockchain, artificial intelligence and others (see Eling and Lehmann (2018) for a detailed list of such innovations) started receiving increasing attention (Willis Tower Watson, 2018). At the same time, investments in Insurtech startups raised from less than 500 USD million in 2012 to more than 2.5 USD billion in 2017 (Milken Institute, 2018), and more than 4 USD billion in 2018 (Willis Tower Watson, 2019).

The population of public US P\&C insurance consists of 40 companies, as in FactSet Fundamentals. Given the non-availability of data in the analyzed period for 5 units, the final sample is a panel of 35 companies, with a representativeness of $99.84 \%$ in terms of collected premiums in 2018 of the overall population of public

\footnotetext{
${ }^{2}$ FactSet Fundamentals is the financial database of FactSet, a market operator with more than 40 years of activity and nearly 10.000 employees globally. Several contributions in literature relied on the FactSet database (Balboa et al., 2008; Baixauli-Soler et al., 2020; Comiran et al., 2018).
} 
Table 3 Control variables values over time

\begin{tabular}{lllll}
\hline & GDP US (M\$) & $\begin{array}{l}\text { 1Y Inter- } \\
\text { est rate } \\
(\%)\end{array}$ & Inflation $^{\mathrm{a}}(\%)$ & Gini index $^{\mathrm{c}}$ \\
\hline 2012 & $16,197,007$ & 0.2 & 2.1 & 0.722 \\
2013 & $16,784,849$ & 0.1 & 1.5 & 0.730 \\
2014 & $17,521,746$ & 0.1 & 1.6 & 0.717 \\
2015 & $18,219,297$ & 0.3 & 0.1 & 0.720 \\
2016 & $18,707,188$ & 0.6 & 1.3 & 0.713 \\
2017 & $19,485,393$ & 1.2 & 2.1 & 0.719 \\
2018 & $20,529,049$ & 2.3 & 2.4 & 0.721 \\
\hline
\end{tabular}

${ }^{\mathrm{a}}$ World Bank

${ }^{b}$ US Dept. of the Treasury $1 Y$ Treasury Bill US—avg Closing Price

'Authors' calculations based on 2018 premiums

Table 4 Correlations among input, output and control variables

\begin{tabular}{|c|c|c|c|c|c|c|c|c|}
\hline & Premiums & Claims & Labor & Capital & GDP & Interest rates & Inflation & Gini index \\
\hline Premiums & 1.00 & & & & & & & \\
\hline Claims & $0.99 * * *$ & 1.00 & & & & & & \\
\hline Labor & $0.96^{* * * *}$ & $0.91 * * *$ & $* 1.00$ & & & & & \\
\hline Capital & $0.87^{* * * *}$ & $0.80^{* * *}$ & $* 0.93 * * *$ & 1.00 & & & & \\
\hline GDP & 0.04 & 0.05 & 0.07 & 0.00 & 1.00 & & & \\
\hline Interest rate & 0.04 & 0.06 & 0.07 & 0.00 & $0.89^{* * *}$ & 1.00 & & \\
\hline Inflation & 0.02 & 0.03 & 0.01 & 0.01 & $0.21 * * *$ & $0.53^{* * *}$ & 1.00 & \\
\hline Gini Index & -0.01 & -0.02 & 0.00 & -0.00 & $-0.39 * * *$ & $-0.13 * *$ & 0.10 & 1.00 \\
\hline
\end{tabular}

$* * *$ p value $<1 \%$;* p value $<5 \%$; p value $<10 \%$

insurance companies active solely in the $\mathrm{P} \& \mathrm{C}$ business. The insurance companies in the sample are diversified in terms of dimensions (see Table 2): indeed, looking at premiums, average amounts of collected premiums are around 4.6 billion USD per year, ranging from a maximum of about 39 billion USD to a minimum of about 7 million USD.

Moreover, considering the parametric technique (SFA), we controlled for Gross Domestic Product (GDP) (Outreville, 1990), interest rates (Beenstock et al., 1988), inflation (Boubaker \& Sghaier, 2014), and concentration (Weiss \& Choi, 2008), relying on the Gini index, in terms of 2018 collected premiums. In particular, as shown in Table 3, concentration in the market remained quite stable over time at around $70 \%$.

Table 4 shows correlations among the variables involved. As we can see, positive correlations are present between the output variable (premiums) and all the input variables ( 0.99 with claims, 0.96 with labor and 0.87 with capital). Control variables, on the other hand, are not particularly correlated with output and input variables. 
Table 5 Technological change factor over the analyzed period

\begin{tabular}{lllllll}
\hline & $2012-2013$ & $2013-2014$ & $2014-2015$ & $2015-2016$ & $2016-2017$ & $2017-2018$ \\
\hline Mean & 1.23 & 0.96 & 1.00 & 0.89 & 1.00 & 1.00 \\
SD & 0.28 & 0.09 & 0.03 & 0.08 & 0.02 & 0.06 \\
Maximum & 2.50 & 1.07 & 1.08 & 1.07 & 1.06 & 1.28 \\
Minimum & 0.97 & 0.53 & 0.96 & 0.77 & 0.94 & 0.89 \\
\hline
\end{tabular}

\section{Results and discussion}

This section presents and discusses main evidence resulting from nonparametric and parametric approaches, relying on the above presented data.

\subsection{Results with a nonparametric approach (two stage-DEA)}

By applying a nonparametric technique, namely two stage-DEA, to analyze the effect of technological change on companies' efficiency, it emerges how, during the considered period, on average the companies in the industry were not gaining efficiency by leveraging technology. Considering the technological change factor resulting from the Malmquist index (Table 5), it emerges how, despite an average improvement in technology from 2012 to 2013 (with a factor of 1.23), during the rest of the period the average technological quality in the industry remained the same in terms of effects on efficiency, and even slightly worsened during 2013-2014 and 2015-2016 (with factors respectively of 0.96 and 0.89). Hence, from 2013, on average the industry was not able to rely on technological innovations to improve its efficiency.

Furthermore, it emerges that no company was able to improve its efficiency over the whole period (even if one company always improved except for once) nevertheless no company suffered a decrease of efficiency in each period (even if six of them were able to improve only once). Hence it is relevant to investigate how the relative level of efficiency among companies (that is, the efficiency of a company with respect to the most efficient ones) changed over time, to understand whether some companies performed better than the others in improving their efficiency, therefore widening the gap with the less efficient ones. From the four two stage-DEA models (input vs output oriented, combined with CRS vs VRS assumption) it emerges how on average the relative level of efficiency among companies did not change, remaining for all models well above $83 \%$ for the whole period, with less efficient companies never lowering their relative efficiency score under 58\%, regardless the model (Table 6). We can therefore conclude that, according to two stage-DEA models, the sector was on average homogeneous in terms of efficiency and maintained this uniformity all along 2012-2018. 
Table 6 Descriptive statistics of efficiency scores estimated with the two-stage DEA approach

\begin{tabular}{|c|c|c|c|c|c|c|c|}
\hline & $2012(\%)$ & $2013(\%)$ & $2014(\%)$ & $2015(\%)$ & $2016(\%)$ & $2017(\%)$ & $2018(\%)$ \\
\hline \multicolumn{8}{|c|}{ CRS input oriented } \\
\hline Mean & 91 & 83 & 84 & 84 & 90 & 88 & 89 \\
\hline SD & 7 & 12 & 11 & 11 & 8 & 9 & 8 \\
\hline Maximum & 100 & 100 & 100 & 100 & 100 & 100 & 100 \\
\hline Minimum & 79 & 58 & 62 & 58 & 72 & 62 & 66 \\
\hline \multicolumn{8}{|c|}{ VRS input oriented } \\
\hline Mean & 97 & 94 & 94 & 94 & 95 & 93 & 94 \\
\hline SD & 5 & 9 & 8 & 8 & 6 & 7 & 7 \\
\hline Maximum & 100 & 100 & 100 & 100 & 100 & 100 & 100 \\
\hline Minimum & 84 & 70 & 75 & 71 & 84 & 80 & 76 \\
\hline \multicolumn{8}{|c|}{ CRS output oriented } \\
\hline Mean & 91 & 83 & 84 & 84 & 90 & 88 & 89 \\
\hline SD & 7 & 12 & 11 & 11 & 8 & 9 & 8 \\
\hline Maximum & 100 & 100 & 100 & 100 & 100 & 100 & 100 \\
\hline Minimum & 79 & 58 & 62 & 58 & 72 & 62 & 66 \\
\hline \multicolumn{8}{|c|}{ VRS output oriented } \\
\hline Mean & 97 & 94 & 94 & 94 & 95 & 93 & 94 \\
\hline $\mathrm{SD}$ & 4 & 8 & 8 & 8 & 6 & 7 & 7 \\
\hline Maximum & 100 & 100 & 100 & 100 & 100 & 100 & 100 \\
\hline Minimum & 85 & 70 & 75 & 73 & 84 & 78 & 76 \\
\hline
\end{tabular}

\subsection{Results with a parametric approach (SFA)}

When it comes to the parametric approach, to identify the most suitable model, we started comparing the two functional forms for the production function, namely the Cobb-Douglas and trans-logarithmic functions. The trans-logarithmic version was rejected (i) being most of the quadratic and interaction variables not significant, and (ii) considering Bayesian information criterion (BIC) and Akaike's information criterion (AIC) results. Hence, focusing on the Cobb-Douglas functional form for the production function (time invariant and time varying models), Table 7 shows the relation between input and output variables. From both models the relation between claims and premiums collected by the insurance companies is positive and significant ( $\mathrm{p}$ value $<1 \%$ ): as mentioned, the estimation of the premium starts from estimating the so-called fair premium, hence the amount needed to cover only expected losses (Zweifel \& Eisen, 2012). In the same way, the relation between labor and premiums is positive and significant for all models ( $\mathrm{p}$ value $<1 \%$ for both models): as highlighted, labor force plays a major role in collecting premiums. Concerning capital, once more the relation with premiums is positive and significant for all models ( $\mathrm{p}$ value $<1 \%$ for both models): capital, as mentioned, is fundamental to enabling insurance activity. It emerges from both models that the technological change had a slightly negative effect on the average industry efficiency: indeed, T parameter is equal to -0.0557 
Table 7 Results of the estimations of SFA models (time invariant and time varying)

Time invariant model (BC88)

Frontier

$\begin{array}{ll}\text { Ln (claims) } & 0.5340 * * *[0.0268] \\ \text { Ln (labor) } & 0.1679 * * *[0.0304] \\ \text { Ln (capital) } & 0.2379 * * *[0.0412] \\ \mathrm{T} & -0.0557 * *[0.0280] \\ \text { Ln (GDP) } & 1.6210 * *[0.7515] \\ \text { Interest Rate } & -1.9399[1.8231] \\ \text { Inflation } & -1.1457 *[0.5235] \\ \text { Gini Index } & 1.7813 *[0.9799] \\ \text { Constant } & 86.0787 *[44.4822]\end{array}$

$\eta$
Time varying model (BC92)

$0.5212 * * *[0.0317]$

$0.1744 * * *[0.0300]$

$0.2487 * * *[0.0429]$

-0.0174 [0.0368]

$1.5614 * *[0.7825]$

-1.4837 [2.0633]

$-1.1194 * *$ [0.5141]

$1.7937 *$ [0.9991]

9.8722 [62.2649]

$-0.0343 *$ [0.0207]

$* * *$ p value $<1 \% ; * *$ p value $<5 \% ; *$ p value $<10 \%$. Standard errors in []

Table 8 Efficiency scores estimated considering a time varying model (BC92): average scores over time and descriptive statistics

\begin{tabular}{lll}
\hline & $\begin{array}{l}\text { Average efficiency scores } \\
(\%)\end{array}$ & Descriptive statistics \\
\hline 2012 & 37.8 & Mean: $35.2 \%$ \\
2013 & 36.3 & SD: $10.3 \%$ \\
2014 & 36.8 & Maximum: $93.3 \%$ \\
2015 & 35.5 & Minimum: $16.8 \%$ \\
2016 & 34.3 & \\
2017 & 33.3 & \\
2018 & 32.1 & \\
\hline
\end{tabular}

in $\mathrm{BC} 88$ ( $\mathrm{p}$ value $<5 \%$ ) and -0.0174 in $\mathrm{BC} 92$. Hence, on average, the companies in the industry were not gaining efficiency by leveraging technology.

The slightly negative (and significant, $\mathrm{p}$ value $<10 \%$ ) value of $\eta$ under BC92 (Table 7) suggests the time varying model to be the most appropriate and will hereby be considered for the discussion. As in nonparametric approaches, we investigated further the efficiency scores, to understand how the relative level of efficiency among companies has changed over time. It emerges that average efficiency levels are quite low (mean $35.2 \%$, standard deviation $10.3 \%$, Table 8 ), constantly decreasing in time, going from $37.8 \%$ to $32.1 \%$, showing a slightly increasing efficiency gap between efficient and less efficient companies over time.

The range of efficiency scores among companies is very wide, going from very efficient companies (score higher than 93\%, Table 8) to not very efficient ones (score of about $16 \%$ ).

Considering the level of heterogeneity, a further investigation of the performance of each single firm shows a very efficient company, better than all the others: indeed, it emerges that, while the efficiency score of the most efficient unit is always well above $90 \%$, considering the second most efficient unit, its score 
is never higher than $49 \%$, about half of the efficiency compared to the most efficient one. These results suggest that we are dealing with an industry composed by one very efficient company, a kind of leader of the market in terms of efficiency, and a homogeneous group of followers. ${ }^{3}$ Therefore, less efficient companies have considerable scope for increasing efficiency, by improving the level of the output, given the amount of inputs, to close the gap with the most efficient company in the group. However, this highly efficient company decreased its efficiency over time (indeed, as suggested by the negative value of parameter $\mathrm{T}$, technological change had the effect of decreasing the efficiency level of the frontier, of which this company is the leader). This, combined with the evidence of a slightly increasing gap, suggest that on average followers decreased their efficiency even further over time. In a competitive scenario, where new players are entering (namely Insurtech players) and competitors have to leverage technology to improve their efficiency, a situation of inertia may seriously affect the positioning of companies, both for the leader and for the followers.

\subsection{Comparing results from nonparametric and parametric approaches}

To summarize, both the nonparametric approach (two-stage DEA) and the parametric approach (SFA) suggest that US public P\&C insurance companies on average, in the period 2012-2018, were not able to leverage technological innovations to improve their efficiency. With a DEA approach, the average technology change index obtained from the Malmquist index was always lower than or equal to one (ranging from 0.89 to 1.00), except for the 2012-2013 transition (with the technology change index equal to 1.23 ), while with the SFA approach, parameter $\mathrm{T}$ was negative (-0.0174), suggesting negative technological change.

Considering the relative level of efficiency among companies (that is, the efficiency of a company compared to the most efficient ones), the two approaches suggest a slightly different message: according to DEA, on average, no companies outperformed the others in improving their efficiency, hence the gap between efficient and less efficient companies did not widen, increasingly confirming the suggestion that the sector is quite homogeneous in terms of companies' efficiency. On the other hand, with the SFA approach, the time varying efficiency model suggested that the efficiency gap slightly opened up during time, hence the distance between efficient and less efficient companies increased.

\footnotetext{
3 Additional analyses omitting the very efficient company confirm positive and significant input coefficients. Additionally, companies in this subsample slightly worsen their technology in terms of effects on efficiency during the analyzed period (i.e. coefficient of $\mathrm{T}-0.0675$, p value $<0.05$ ). The companies' average relative efficiency is more than twice higher than before in most of the cases (due to the absence of the very efficient company and to the consequent recalibration of scores), and BC92 suggests a fairly stable gap. Results are similar even when re-running the two-stage DEA.
} 


\section{Conclusions}

Technological innovations such as artificial intelligence (McKinsey, 2018a), blockchain (BCG, 2018) and big data (Corlosquet-Habart \& Janssen, 2018) are creating new opportunities in the insurance sector, with the promise of increasing efficiency (Lin \& Chen, 2020). Despite these suggestions, literature empirically assessing whether insurance companies over the past few years were able to leverage new technologies to improve efficiency is scarce.

Focusing on the US public $\mathrm{P} \& \mathrm{C}$ insurance sector and relying on both a nonparametric (two stage-DEA) and a parametric (SFA) approach to find evidence of higher efficiency supported by technological improvements, it emerges that on average insurance companies were not able to leverage technological innovations to improve their efficiency. These results suggest that, despite relevant opportunities and promises claimed by new technologies in the insurance sector, it is relevant to understand how to practically rely on these innovations in order to improve processes and consequently gain efficiency. Often, to reduce costs insurance companies have instead put in place cost-cutting strategies (McKinsey, 2019). Large and complex firms indeed usually take longer to fully exploit new technologies in their value chain and upskill workforce to properly benefit from them, as suggested by Damioli et al. (2021) for the case of Artificial Intelligence. Further investigating the efficiency scores, in order to understand how the relative level of efficiency among companies has changed, the two approaches suggest a slightly different message. While DEA results support that on average, no companies outperformed the others in improving their efficiency by leveraging technology, indicating that the level of relative efficiency in the industry was quite stable over time, the SFA approach shows a slightly widening gap between efficient and less efficient companies. Moreover, we found a very efficient company, a kind of leader, and a homogeneous group of followers, indicating that there is vast space for improvement for less efficient firms. Nevertheless, the lacking gap closure was not due to significant improvements of the most efficient company, that if anything worsened its efficiency during time, but to an average reduction in efficiency of its followers, suggesting that neither the leader nor on average the followers properly leveraged technology in the analyzed period in order to improve their efficiency. In a competitive scenario, where new players are entering (namely Insurtech players) and competitors need to leverage technology to improve their efficiency, a situation of inertia may seriously affect the positioning of companies, both for the leader and for the followers.

Considering the results and the mentioned promises to increase efficiency by recent technological innovations (Lin \& Chen, 2020), these findings suggest the need to further investigate best practices in adopting technologies to create efficiency and, in general, to bring the promised benefits in the industry. Not just academicians, but also managers and policy makers should carefully consider the effects that a non-improvement of efficiency following technological change may have on the market structure, its competition and regulations, potentially opening to further discussion on how technological innovations should be grounded and 
effectively adopted or facilitated. For policy makers, this work aims at providing the basis for understanding on one hand how regulations could maximize the effect of technology on efficiency improvements, and on the other hand which measures should be put in place, depending on the view of the regulator, to either reduce the efficiency gap between companies or to consolidate the industry fostering only a few efficient players. Non-efficient insurance companies are more likely to default (Ilyas \& Rajasekaran, 2019), as well as companies not leveraging technological innovations (Christensen, 2013). With a similar approach, future research should investigate on how new regulatory frameworks, business models and the changing environment are affecting efficiency for insurance companies.

Acknowledgements The authors would like to thank the anonymous Reviewers and the Editor for their valuable comments and suggestions that greatly contributed to the improvement of the quality of this paper. We would also like to express our gratitude to Davide Scotti who kindly reviewed an earlier version of this manuscript and to Dorin Agache for providing access to FactSet financial database.

Funding Open access funding provided by Politecnico di Milano within the CRUI-CARE Agreement. No funding was received.

Availability of data and material Not applicable.

Code availability Not applicable.

\section{Declaration}

Conflicts of interest No conflicts of interest/competing interests were present.

Open Access This article is licensed under a Creative Commons Attribution 4.0 International License, which permits use, sharing, adaptation, distribution and reproduction in any medium or format, as long as you give appropriate credit to the original author(s) and the source, provide a link to the Creative Commons licence, and indicate if changes were made. The images or other third party material in this article are included in the article's Creative Commons licence, unless indicated otherwise in a credit line to the material. If material is not included in the article's Creative Commons licence and your intended use is not permitted by statutory regulation or exceeds the permitted use, you will need to obtain permission directly from the copyright holder. To view a copy of this licence, visit http://creativecommons.org/licen ses/by/4.0/.

\section{References}

Alhassan, A. L., \& Biekpe, N. (2016). Competition and efficiency in the non-life insurance market in South Africa. Journal of Economic Studies, 43(6), 882-909.

Al-witwit, S. S. I., \& Ibrahim, A. A. (2020, November). Improving Operational Efficiency of Government using Artificial Intelligence. In IOP Conference Series: Materials Science and Engineering (Vol. 928, No. 2, p. 022014). IOP Publishing.

Baixauli-Soler, J. S., Lozano-Reina, G., \& Sánchez-Marín, G. (2020). Managerial discretion, say on pay, and CEO compensation. Management Decision, 59(6), 1333-1362.

Balboa, M., Gomez-Sala, J. C., \& Lopez-Espinosa, G. (2008). Does the value of recommendations depend on the level of optimism? A country-based analysis. Journal of Multinational Financial Management, 18(4), 405-426.

Banker, R. D., Charnes, A., \& Cooper, W. W. (1984). Some models for estimating technical and scale inefficiencies in data envelopment analysis. Management Science, 30(9), 1078-1092. 
Barros, C., Barroso, N., \& Borges, M. (2005). Evaluating the efficiency and productivity of insurance companies with a Malmquist index: A case study for Portugal. The Geneva Papers on Risk and Insurance-Issues and Practice, 30(2), 244-267.

Bartelsman, E. J., Falk, M., Hagsten, E., \& Polder, M. (2019). Productivity, technological innovations and broadband connectivity: Firm-level evidence for ten European countries. Eurasian Business Review, 9(1), 25-48.

Battese, G., \& Coelli, T. (1988). Prediction of firm-level technical efficiencies with a generalized frontier production function and panel data. Journal of Econometrics, 38(1988), 387-399.

Battese, G., \& Coelli, T. (1992). Frontier production functions, technical efficiency and panel data: With application to paddy farmers in India. Journal of Productivity Analysis, 3(1/2), 153-169.

Battese, G. E., \& Rao, D. P. (2002). Technology gap, efficiency, and a stochastic metafrontier function. International Journal of Business and Economics, 1(2), 87.

BCG. (2018). The First All Blockchain Insurer. By Roberto Bosisio, Kaj Burchardi, and Max Hauser. https://www.bcg.com/it-it/publications/2018/first-all-blockchain-insurer.

Beenstock, M., Dickinson, G., \& Khajuria, S. (1988). The relationship between property-liability insurance premiums and income: an international analysis. The Journal of Risk and Insurance, 55(2), 259-272.

Berger, A. N. (1993). "Distribution-free" estimates of efficiency in the US banking industry and tests of the standard distributional assumptions. Journal of Productivity Analysis, 4(3), 261-292.

Biener, C., Eling, M., \& Wirfs, J. H. (2016). The determinants of efficiency and productivity in the Swiss insurance industry. European Journal of Operational Research, 248(2), 703-714.

Bohnert, A., Fritzsche, A., \& Gregor, S. (2019). Digital agendas in the insurance industry: The importance of comprehensive approaches. The Geneva Papers on Risk and Insurance-Issues and Practice, 44(1), 1-19.

Boubaker, H., \& Sghaier, N. (2014). How do the interest rate and the inflation rate affect the non-life insurance premiums? Working Papers 2014-282, Department of Research, Ipag Business School.

Boussofiane, A., Dyson, R. G., \& Thanassoulis, E. (1991). Applied data envelopment analysis. European Journal of Operational Research, 52(1), 1-15.

Camino-Mogro, S., \& Bermúdez-Barrezueta, N. (2019). Determinants of profitability of life and non-life insurance companies: Evidence from Ecuador. International Journal of Emerging Markets, 14(5), 831-872.

Charnes, A., Cooper, W. W., \& Rhodes, E. (1978). Measuring the efficiency of decision making units. European Journal of Operational Research, 2(6), 429-444.

Christensen, C. M. (2013). The innovator's dilemma: when new technologies cause great firms to fail. Harvard Business Review Press.

Clemente, G. P., \& Marano, P. (2020). The broker model for peer-to-peer insurance: An analysis of its value. The Geneva Papers on Risk and Insurance-Issues and Practice, 45(3), 457-481.

Comiran, F., Fedyk, T., \& Ha, J. (2018). Accounting quality and media attention around seasoned equity offerings. International Journal of Accounting \& Information Management., 26(3), 443-462.

Cooper, W. W., Seiford, L. M., \& Zhu, J. (2011). Handbook on data envelopment analysis (Vol. 164). Springer Science \& Business Media.

Copeland, M. K., \& Cabanda, E. (2018). Efficiency analysis of the US publicly held insurance industry: a two-stage efficiency model. International Journal of Information Systems in the Service Sector (IJISSS), 10(1), 1-15.

Corlosquet-Habart, M., \& Janssen, J. (2018). Big Data for Insurance Companies. Wiley.

Cummins, J. D. (1999). Efficiency in the US life insurance industry: Are insurers minimizing costs and maximizing revenues? Changes in the Life Insurance Industry: Efficiency, Technology and Risk Management (pp. 75-115). Springer.

Cummins, J. D., \& Turchetti, G. (1996). Productivity and technical efficiency in the Italian insurance industry (No 96-10). Wharton School Center for Financial Institutions, University of Pennsylvania.

Cummins, J. D., \& Weiss, M. A. (2013). Analyzing firm performance in the insurance industry using frontier efficiency and productivity methods. Handbook of Insurance (pp. 795-861). Springer.

Cummins, J. D., \& Xie, X. (2016). Efficiency and productivity in the US property-liability insurance industry: ownership structure, product and distribution strategies. Data Envelopment Analysis (pp. 113-163). Springer.

Damioli, G., Van Roy, V., \& Vertesy, D. (2021). The impact of artificial intelligence on labor productivity. Eurasian Business Review, 11(1), 1-25. 
Danquah, M., Otoo, D. M., \& Baah-Nuakoh, A. (2018). Cost efficiency of insurance firms in Ghana. Managerial and Decision Economics, 39(2), 213-225.

Delhausse, B., Fecher, F., \& Pestieau, P. (1995). Measuring productive performance in the non-life insurance industry: The case of French and Belgian markets. Tijdschrift Voor Economie En Management, 40(1), 47-69.

Deloitte. (2018). Insurtech entering second wave. https:/www2.deloitte.com/content/dam/Deloitte/us/ Documents/financial-services/us-dcfs-insurtech-entering-second-wave.pdf.

Deloitte. (2019). 2020 Insurance Outlook. Insurers adapt to grow in a volatile economy. https://www2. deloitte.com/content/dam/insights/us/articles/6304_Insurance-outlook/DI_Insurance-outlook.pdf.

Eling, M., \& Lehmann, M. (2018). The impact of digitalization on the insurance value chain and the insurability of risks. The Geneva Papers on Risk and Insurance-Issues and Practice, 43(3), 359-396.

Eling, M., \& Luhnen, M. (2010). Efficiency in the international insurance industry: A cross-country comparison. Journal of Banking \& Finance, 34(7), 1497-1509.

EY. (2019). 2020 US and Americas Insurance Outlook. https://assets.ey.com/content/dam/ey-sites/eycom/en_gl/topics/insurance/insurance-outlook-pdfs/ey-global-insurance-outlook-us-americas_v2. pdf.

Fecher, F., Kessler, D., Perelman, S., \& Pestieau, P. (1993). Productive performance of the French insurance industry. Journal of Productivity Analysis, 4(1-2), 77-93.

Ferro, G., \& León, S. (2018). A stochastic frontier analysis of efficiency in Argentina's non-life insurance market. The Geneva Papers on Risk and Insurance-Issues and Practice, 43(1), 158-174.

Fitzgerald, M., Kruschwitz, N., Bonnet, D., \& Welch, M. (2014). Embracing digital technology: A new strategic imperative. MIT Sloan Management Review, 55(2), 1-12.

Fried, H. O., Schmidt, S. S., \& Lovell, C. K. (1993). The measurement of productive efficiency: Techniques and applications. Oxford University Press.

Fuentes, H., Grifell-Tatje, E. \& Perelman, S. (2005). Product specialization, efficiency and productivity change in the Spanish insurance industry. CREPP Working Papers 0506, Universite de Liege

Gomulka, S. (2006). The theory of technological change and economic growth. Routledge.

Greene, W. H. (2008). The econometric approach to efficiency analysis. The Measurement of Productive Efficiency and Productivity Growth, 1(1), 92-250.

Grima, S., Spiteri, J., \& Romānova, I. (2020). A STEEP framework analysis of the key factors impacting the use of blockchain technology in the insurance industry. The Geneva Papers on Risk and Insurance-Issues and Practice, 45(3), 398-425.

Grmanová, E., \& Strunz, H. (2017). Efficiency of insurance companies: Application of DEA and Tobit analyses. Journal of International Studies, 10(3), 250-263.

Hauswald, R., \& Marquez, R. (2003). Information technology and financial services competition. The Review of Financial Studies, 16(3), 921-948.

Hesarzadeh, R. (2020). Regulatory oversight and managerial ability. Eurasian Business Review, 10(4), 559-585.

Huang, W., \& Eling, M. (2013). An efficiency comparison of the non-life insurance industry in the BRIC countries. European Journal of Operational Research, 226(3), 577-591.

Ilyas, A. M., \& Rajasekaran, S. (2019). An empirical investigation of efficiency and productivity in the Indian non-life insurance market. Benchmarking: an International Journal, 26(7), 2343-2371.

Jarraya, B., \& Bouri, A. (2015). A new assessment approach of technical efficiency and productivity in European non-life insurance companies. International Journal of Managerial and Financial Accounting, 7(3-4), 217-234.

Lee, C., \& Ji, Y. B. (2009, July). Data envelopment analysis in Stata. In Stata Conference DC.

Lee, K. R., Leem, B., Lee, C. W., \& Lee, C. (2011). Malmquist Productivity Index using DEA frontier in Stata. Stata Journal, 2(2), 1-9.

Li, H., Chen, C., Cook, W. D., Zhang, J., \& Zhu, J. (2018). Two-stage network DEA: Who is the leader? Omega, 74(2018), 15-19.

Lin, L., \& Chen, C. C. (2020). The Promise and Perils of InsurTech. Forthcoming, Singapore Journal of Legal Studies.

Marchionni, F. (2006). L'impresa assicurativa: fabbrica, finanza e ruolo sociale. Il sole 24 ore.

McKinsey. (2018a). Insurance 2030-The impact of AI on the future of insurance. By Ramnath Balasubramanian, Ari Libarikian, and Doug McElhaney. https://www.mckinsey.com/industries/financial-servi ces/our-insights/insurance-2030-the-impact-of-ai-on-the-future-of-insurance. 
McKinsey. (2018b). Digital Insurance in 2018. https://www.mckinsey.com/ /media/mckinsey/industries/ financial\%20services/our\%20insights/digital\%20insurance\%20in\%202018\%20driving\%20real\% 20impact\%20with\%20digital\%20and\%20analytics/digital-insurance-in-2018.ashx.

McKinsey. (2019). The productivity imperative in insurance. By Bernhard Kotanko, Björn Münstermann, Pradip Patiath, Jasper van Ouwerkerk, and Ulrike Vogelgesang. https://www.mckinsey.com/indus tries/financial-services/our-insights/the-productivity-imperative-in-insurance.

Milken Institute. (2018). InsurTech Rising: A Profile of the InsurTech Landscape. By Jackson Mueller. https://milkeninstitute.org/sites/default/files/reports-pdf/InsurTech-Rising-12.4.18_2.pdf.

Mogos, S., Davis, A., \& Baptista, R. (2021). High and sustainable growth: Persistence, volatility, and survival of high growth firms. Eurasian Business Review, 11(1), 135-161.

Nam, S. (2018). How much are insurance consumers willing to pay for Blockchain and smart contracts? A contingent valuation study. Sustainability, 10(11), 4332.

Nguyen, L., \& Worthington, A. C. (2020). Industry regulation, fund characteristics, and the efficiency of Australian private health insurers. Accounting \& Finance, 61(2021), 781-801.

Nourani, M., Kweh, Q. L., Devadason, E. S., \& Chandran, V. G. R. (2020). A decomposition analysis of managerial efficiency for the insurance companies: A data envelopment analysis approach. Managerial and Decision Economics., 41(6), 885-901.

NTT Data, Everis. (2020). Insurtech global outlook 2020. https://insurtechnttdata.everis.com/dist/resou rces/vlarrosa/insurtech/Insurtech-Global-Outlook_Report.pdf.

Outreville, J. F. (1990). The economic significance of insurance markets in developing countries. Journal of Risk and Insurance, 57(3), 487-498.

Pellegrino, G., \& Piva, M. (2020). Innovation, industry and firm age: Are there new knowledge production functions? Eurasian Business Review, 10(1), 65-95.

Rai, A. (1996). Cost efficiency of international insurance firms. Journal of Financial Services Research, 10(3), 213-233

Schaeck, K., \& Cihák, M. (2014). Competition, efficiency, and stability in banking. Financial Management, 43(1), 215-241.

Shieh, H. S., Hu, J. L., \& Ang, Y. Z. (2020). Efficiency of life insurance companies: an empirical study in Mainland China and Taiwan. SAGE Open, 10(1), 2158244020902060.

Smith, A. (2007). An Inquiry into the Nature and Causes of the Wealth of Nations edited by SM Soares. MetaLibri Digital Library, 5(8), 5.

Sonenshine, R. (2020). Merger waves: Are buyers following the herd or responding to structural queues? Eurasian Business Review, 10(2), 287-308.

Stoeckli, E., Dremel, C., \& Uebernickel, F. (2018). Exploring characteristics and transformational capabilities of InsurTech innovations to understand insurance value creation in a digital world. Electronic Markets, 28(3), 287-305.

Swiss Re Institute. (2020). Sigma I World insurance: riding out the 2020 pandemic storm. https://www. swissre.com/dam/jcr:d50acbcd-ce5c-4ee9-bc60-a3c1e55f8762/sigma-4-2020-en.pdf.

The Geneva Association. (2012). The Social and Economic Value of Insurance. https://www.genevaasso ciation.org/sites/default/files/research-topics-document-type/pdf_public//ga2012-the_social_and_ economic_value_of_insurance.pdf.

Tuzcu, S. E., \& Ertugay, E. (2020). Is size an input in the mutual fund performance evaluation with DEA? Eurasian Economic Review, 10(4), 635-659.

Ur-Rehman, R., Zhang, J., Naseem, M. A., Ahmed, M. I., \& Ali, R. (2020). Board independence and Chinese banking efficiency: a moderating role of ownership restructuring. Eurasian Business Review, $11,1-20$.

Vecchiato, R. (2017). Disruptive innovation, managerial cognition, and technology competition outcomes. Technological Forecasting and Social Change, 116(2017), 116-128.

Voghouei, H., \& Jamali, M. A. (2018). Determinants of government efficiency: Does information technology play a role? Eurasian Business Review, 8(3), 285-298.

Weiss, M. A., \& Choi, B. P. (2008). State regulation and the structure, conduct, efficiency and performance of US auto insurers. Journal of Banking \& Finance, 32(1), 134-156.

Willis Tower Watson. (2018). Quarterly InsurTech Briefing Q1 2018. https://www.willistowerswatson. com/-/media/WTW/Insights/2018/05/quarterly-insurtech-briefing-q1-2018.pdf? modified=20180 521173321.

Willis Tower Watson. (2019). Quarterly InsurTech Briefing Q4 2018. https://www.willistowerswatson. com/-/media/WTW/Insights/2019/02/quarterly-insurtech-briefing-q4-2018.pdf?modified=20190 228155910. 
Worthington, A. C., \& Hurley, E. V. (2002). Cost efficiency in Australian general insurers: A non-parametric approach. The British Accounting Review, 34(2), 89-108.

Zweifel, P., \& Eisen, R. (2012). Insurance economics. Springer Science \& Business Media.

Publisher's Note Springer Nature remains neutral with regard to jurisdictional claims in published maps and institutional affiliations. 